\title{
Poaceae pollen grain size as a tool to distinguish past grasslands in South America: a new methodological approach
}

\author{
Lisa Schüler • Hermann Behling
}

Received: 19 November 2009/Accepted: 17 May 2010/Published online: 30 September 2010

(C) The Author(s) 2010. This article is published with open access at Springerlink.com

\begin{abstract}
Despite the dominance of grasslands during the last glacial period, especially in South America, the highly uniform morphology of Poaceae pollen grains has so far allowed only very few palynological studies based on Poaceae pollen. In our study we compare two methods of distinguishing between South American grassland ecosystems based on quantitative morphology of Poaceae pollen grains. We investigated data sets from Páramo in southern Ecuador, Campos de Altitude and Campos in south-eastern and southern Brazil as well as data sets from the Pampa in Argentina by measuring the pollen grain length, grain width, pore diameter and annulus width. Firstly we investigated the potential influence of chemical treatment of pollen grains on pollen grain size as well as the measurement setting for defining the boundary conditions for using Poaceae pollen grains in a palaeoecological investigation. Finally the measured pollen grain parameters were analyzed by comparison of average grain length using statistical tests. This approach reveals highly significant differences in average grain size between all grassland ecosystems. Assuming that a certain grain size range can be assigned to a certain Poaceae taxon, conclusions about differences and similarities in taxa composition can be derived. We used two methods of multivariate data analysis. One uses the pollen grain parameters directly for a Principle Component Analysis (PCA). The other is an already established method in grassland ecology which
\end{abstract}

Communicated by A.F. Lotter.

L. Schüler $(\bowtie) \cdot$ H. Behling

Department of Palynology and Climate Dynamics,

Albrecht-von-Haller-Institute for Plant Sciences,

Georg-August-University of Göttingen, Untere Karspüle 2,

37073 Göttingen, Germany

e-mail: Lisa.Schueler@biologie.uni-goettingen.de defines parameter based pollen grain types to investigate similarities between grassland ecosystems. Both approaches confirm the results of the grain length analysis. In this work we demonstrate that the method we developed has the potential to provide acquisition of so far inaccessible information on spatial and temporal patterns and dynamics of South American grasslands.

Keywords Palynology $\cdot$ Poaceae $\cdot$ South America Páramo - Campos · Campos de Altitude · Pampa . Grasslands

\section{Introduction}

Grass pollen dominates the palaeoecological record from South America during the Late Glacial (Behling and Hooghiemstra 2001; Behling et al. 2004; Brunschön and Behling 2009; Haberle and Maslin 1999; Prieto 1996). However, the interpretation of the grass signal and reconstruction of the ecosystems that it probably represents is hampered by the limited family level identification possible and the variety of settings within which grasses are abundant. Present grassland ecosystems in South America are among the most biodiverse areas of the world (Alves and Kolbek 1994; Boldrini 2009; Overbeck et al. 2007; Sklenár and Balslev 2005; Soriano et al. 1992) and are subject to conservation activities. During the Pleistocene these grassland ecosystems were much more dominant (Behling and Pillar 2008; Overbeck et al. 2005, 2007). Spatial variations of subtropical and tropical grassland ecosystems, as well as changes in vegetation composition, locations and boundary shifts play an important role in past climate reconstruction (Behling 2002). In order to understand the different grassland areas today, especially for conservation 
management, we need to investigate their origin, development and dynamics.

Species based investigations on palaeo-grasslands are not very sophisticated since the use of palynological methods based on the dominant family, the Poaceae, in this vegetation type is very difficult. Studies on accompanying flora have been able to give at least a hint on differences between grassland ecosystems (Behling et al. 2004). Further approaches using phytoliths have been accomplished (Fernandéz Honaine et al. 2006, 2009; Iriarte 2003, 2006) and have provided a more detailed insight into these important ecosystems. Also, phytoliths are used to derive further information on grassland dynamics (e.g. Alexandre et al. 1997; Scott 2002; Strömberg 2004). Other studies based on the differences in stable isotope composition $\left(\delta^{13} \mathrm{C}\right)$ between $\mathrm{C} 3$ and $\mathrm{C} 4$ grasses, and hence their pollen grains, revealed that the abundance of these two functional groups can be estimated in palaeorecords (Amundson et al. 1997; Nelson et al. 2006, 2007, 2008).

\section{Poaceae species diversity}

The family Poaceae (Gramineae) is cosmopolitan and comprises about 12,000 species in about 700 genera worldwide. In South America 214 Poaceae genera are known (Nicora and Rúgulo de Agasar 1987). Hardly any literature is available concerning species numbers of specific areas or even countries. Despite this incompleteness of information, the enormous number of more than 450 known species in southern Brazil alone (Boldrini 2009) gives a first indication of what numbers and species diversity to expect in the whole South American continent, and hence, in the different grasslands herein.

Considering the rather sparse knowledge of Poaceae pollen grains of wild species in Europe, it becomes evident why the state of identification of Neotropical Poaceae and their differentiation using a palynological approach has not progressed, as even less information is available on South American grass pollen grain morphology.

\section{Morphological differentiation of pollen grains}

Palynology faces the problem of a uniform morphology of Poaceae pollen grains. They are well known to be very homogenous (Beug 1961; Salgado-Labouriau and Rinaldi 1990a, b) which makes it easy to recognise them. However, the identification at genus or at subfamily level, especially of wild grass species remains very difficult (Joly et al. 2007). Pivotal details only become visible using a >600$1000 \times$ magnification and oil immersion light microscopy
(Joly et al. 2007; Roubik and Moreno 1991). However when aiming at determining a representative amount of grains using a $400 \times$ magnification, this is very intricate and time-consuming.

According to Beug (1961) the pore diameter as well as annulus shape and size are the principle characteristics for distinction between Poaceae. Species of the mixed group can be identified by observing the pattern of the columellae (Beug 2004). The fine sculpture of the exine has also been used for the distinction between cereals and wild grasses (Köhler and Lange 1979). However, thresholds in parameter size differ between the studies and no definite criteria for discrimination emerge which could be useful for all study areas. In a study on Avena sativa Katsiotis and Forsberg (1995) discovered that the grain size increases with the ploidy level. Additionally, the authors found a positive correlation between major and minor axis of the grains.

Poaceae taxa seem to display a rather variable size range at species level (Salgado-Labouriau and Rinaldi 1990a). Beug (1961) has already suggested an intraspecific wide range of grain sizes. European Poaceae pollen grains of wild species were found to display very large size ranges reaching $\sim 10 \mu \mathrm{m}$ as maximum deviation from the mean (Beug 1961; Rohde 1959). Salgado-Labouriau and Rinaldi (1990a) ascertained that the variation in size of cultivated grasses is higher than in wild grass species. This was also confirmed by a study on Zea mays L. and Teosinte (wild maize) (Holst et al. 2007).

The maximum variation found within the species investigated by Salgado-Labouriau and Rinaldi (1990a) was $\sim 4 \mu \mathrm{m}$ (Chusquea fendleri); minimum variation of around $2 \mu \mathrm{m}$ was found in the species Pharus glaber and Muhlenbergia implicata.

The pollen grain size variation at genus level is mostly high (Joly et al. 2007; Salgado-Labouriau and Rinaldi 1990a). Woody Bambusoideae were thought to have persistently large pollen grains $(>36.4 \mu \mathrm{m})$ (SalgadoLabouriau and Rinaldi 1990a), but this however has been disproved when considering a higher number of taxa (Bush, personal communication). Hence, so far, there is no evidence that a phylogentic pattern at genus level exists.

Since the species numbers of Poaceae in South America are high, no extensive palynological studies exist in this field. Most palaeo-ecological investigations leave Poaceae as the dominating taxon without distinguishing further to subfamily or genus level. However, palynologists perceive great differences in pollen grain size of Poaceae, but so far no convenient method for analysing this has existed, that was not excessively time consuming and hence compatible with palynological analysis of samples. This often poses a problem to researchers working in this field (Gosling et al. 2009). 


\section{Influence of pollen preparation}

Pollen preparation and storage can have an impact on the pollen grain size. $\mathrm{KOH}$ treatment is suspected to increase the size significantly when used in combination with acetolysis (Dickson 1988). Also hydrofluoric acid (HF) has been observed to alter the grain size. An increase in size of grass pollen grains is known from storage of 6-7 years as observed by Hamilton (1972); however, the largest increase takes place within the first 4-5 days after mounting (Andersen 1979; Bolbochan and Salgado-Labouriau 1983). The thickness of slides may also impact the grain size (Cushing 1961). Concerning mounting medium, glycerol jelly tends to swell the grains about 1.25 times compared to silicone oil treatment, which does not appear to cause swelling (Moore and Webb 1978). However, a recent study performed with Carex pollen grains showed that the intraspecific variation of size was greater than the variation that could be observed due to different chemical treatments (Meltsov et al. 2008).

Despite the difficulties in species discrimination there is the need for a tool for investigating palaeo-grasslands more extensively. We collected data on measurable parameters of Poaceae pollen grains to develop a relatively quick and effective method of classifying taxa and distinguishing between grassland ecosystems. Salgado-Labouriau and Rinaldi (1990a, b) predict that different types of vegetation are not represented by a characteristic size distribution of grass pollen grains, since in their study the grain size range of Poaceae of the Cerrado ecosystem is included within the range of the Venezuelan mountain species. The authors further presume that grain size distribution for most vegetation types would follow a Gaussian distribution if the diversity is high. Only very large or very small grains would enable a differentiation. With our method, we want to test whether a more detailed differentiation on a spatial and temporal scale is possible when using several morphological parameters of grass pollen grains.

In this paper we describe two methods of finding patterns that distinguish grassland ecosystems based on Poaceae pollen grains. The first method uses a Principle Component Analysis (PCA) with single pollen grains. The second approach follows the method of Pillar and Sosinksi (2003) and Pillar et al. (2009), which was developed to find assembly patterns in plant functional types using numerical analysis. This approach is already established in vegetation ecology and will be used to evaluate the results of our method.

While in this paper, analyses remain on a macro scale to introduce the method, in a follow-up study on the application of this method to South American grasslands, we draw conclusions about Poaceae taxa composition within one grassland ecosystem based on the grain size ranges and about differences between grassland ecosystems (Schüler and Behling 2010).

For our investigations, we chose samples from different grassland ecosystems and of different ages and locations within the ecosystems. The purpose of this was to allow macro scale analyses between ecosystems on the one hand and micro scale analyses within one ecosystem on the other hand. For the establishment of the method it was not necessary to include modern pollen since, up to now, there is as little known about the morphology of modern Poaceae pollen grains as about those from the past. For calibration purposes, it will nevertheless be useful to examine the size composition of modern Poaceae pollen.

\section{Materials and methods}

\section{Material}

We investigated 20 samples (Table 1) from nine different cores representing four different grassland ecosystems in South America (Fig. 1). The ecosystems range through Páramo in southern Ecuador, Campos de Altitude in southeastern Brazil, Campos in southern Brazil and Pampa in Argentina. The samples selected within a core were determined by the presence of grassland vegetation. This information was derived from pollen diagrams that already exist for the study sites (Brunschön and Behling 2009; Páramo: Niemann and Behling 2010; Niemann et al. 2009; Campos de Altitude: Behling, unpubl.; Campos: Behling et al. 2004; Pampa: Prieto 1996, 2000). The radiocarbon age of the samples was calibrated with the CalPal online software (Danzeglocke et al. 2009).

From the Páramo we investigated ten samples from five different sites in southern Ecuador ranging between 530 and $23600 \mathrm{cal}$ year B.P. The different core sites represent Páramo vegetation between $2,820 \mathrm{~m}$ to $3,790 \mathrm{~m}$ a.s.l.

The six Campos samples are all taken from a single core located at about $1,000 \mathrm{~m}$ a.s.l. in southern Brazil. The age of the samples ranges from 46020 to $150 \mathrm{cal}$ year B.P.

From each of the two sites in Campos de Altitude vegetation (at 2,400 $\mathrm{m}$ a.s.l.) we took one sample, which are both dated to 190 cal year в.P. Finally, from the Pampa in Argentina we investigated two samples from the same site, dated to 6500 and 7460 cal year B.P.

Methods

\section{Preparatory work}

The preparatory work aimed at assuring the prerequisites of the new method concerning the sample preparation, 
Table 1 Information on location, sampling depth, vegetation type, elevation of coring site and coordinates of the investigated samples. Reference to pollen diagrams, which were retrieved for sample selection, is also given

\begin{tabular}{|c|c|c|c|c|c|c|}
\hline Location & $\begin{array}{l}\text { Sample } \\
\text { depth }(\mathrm{cm})\end{array}$ & $\begin{array}{l}\text { Cal age } \\
\text { (yrs B.P.) }\end{array}$ & $\begin{array}{l}\text { Present } \\
\text { vegetation }\end{array}$ & $\begin{array}{l}\text { Elevation } \\
\text { (m a.s.1.) }\end{array}$ & Coordinates & Reference \\
\hline Lago Azul & 10 & 190 & $\begin{array}{c}\text { Campos de } \\
\text { Altitude }\end{array}$ & 2,400 & Itajaia mountains & Unpubl. \\
\hline Lago Agulhas Negras & 10 & 190 & $\begin{array}{c}\text { Campos de } \\
\text { Altitude }\end{array}$ & 2,400 & Itajaia mountains & Unpubl. \\
\hline Cambara do Sul & 13 & 150 & Campos & 1,000 & $29^{\circ} 2^{\prime} 14.76^{\prime \prime}$ S $50^{\circ} 9^{\prime} 20.24^{\prime \prime} \mathrm{W}$ & Behling et al. 2004 \\
\hline Cambara do Sul & 63 & 1850 & Campos & 1,000 & $29^{\circ} 2^{\prime} 14.76^{\prime \prime} \mathrm{S} 50^{\circ} 9^{\prime} 20.24^{\prime \prime} \mathrm{W}$ & Behling et al. 2004 \\
\hline Cambara do Sul & 95 & 7800 & Campos & 1,000 & $29^{\circ} 2^{\prime} 14.76^{\prime \prime}$ S $50^{\circ} 9^{\prime} 20.24^{\prime \prime} \mathrm{W}$ & Behling et al. 2004 \\
\hline Cambara do Sul & 125 & 22630 & Campos & 1,000 & $29^{\circ} 2^{\prime} 14.76^{\prime \prime}$ S $50^{\circ} 9^{\prime} 20.24^{\prime \prime} \mathrm{W}$ & Behling et al. 2004 \\
\hline Cambara do Sul & 180 & 41930 & Campos & 1,000 & $29^{\circ} 2^{\prime} 14.76^{\prime \prime} \mathrm{S} 50^{\circ} 9^{\prime} 20.24^{\prime \prime} \mathrm{W}$ & Behling et al. 2004 \\
\hline Cambara do Sul & 210 & 46020 & Campos & 1,000 & $29^{\circ} 2^{\prime} 14.76^{\prime \prime}$ S $50^{\circ} 9^{\prime} 20.24^{\prime \prime} \mathrm{W}$ & Behling et al. 2004 \\
\hline Arrayo Claromecó & & 6500 & Pampa & & $38^{\circ} 50^{\prime} \mathrm{S} 60^{\circ} 05^{\prime} \mathrm{W}$ & Unpubl. \\
\hline Arrayo Claromecó & & 7460 & Pampa & & $38^{\circ} 50^{\prime} \mathrm{S} 60^{\circ} 05^{\prime} \mathrm{W}$ & Unpubl. \\
\hline Cerro Toledo & 60 & 530 & Páramo & 3,148 & $04^{\circ} 22^{\prime} 28.6^{\prime \prime} \mathrm{S} 079^{\circ} 06^{\prime} 41.5^{\prime \prime} \mathrm{W}$ & Brunschön and Behling 2009 \\
\hline Rabadilla de Vaca & 50 & 830 & Páramo & 3,312 & $04^{\circ} 15^{\prime} 19.7^{\prime \prime} \mathrm{S} 079^{\circ} 06^{\prime} 43.7^{\prime \prime} \mathrm{W}$ & Niemann et al. 2009 \\
\hline Tres Lagunas & 25 & 1000 & Páramo & 3,788 & $03^{\circ} 02^{\prime} 50.9^{\prime \prime} \mathrm{S} 079^{\circ} 14^{\prime} 29.9^{\prime \prime} \mathrm{W}$ & Brunschön and Rodriguez unpubl. \\
\hline Tres Lagunas & 111 & 7740 & Páramo & 3,788 & $03^{\circ} 02^{\prime} 50.9^{\prime \prime} \mathrm{S} 079^{\circ} 14^{\prime} 29.9^{\prime \prime} \mathrm{W}$ & Brunschön and Rodriguez unpubl. \\
\hline El Tiro & 85 & 12460 & Páramo & 2,817 & $03^{\circ} 59^{\prime} 23.2^{\prime \prime} \mathrm{S} 079^{\circ} 08^{\prime} 42.7^{\prime \prime} \mathrm{W}$ & Niemann and Behling 2008 \\
\hline El Tiro & 101 & 13070 & Páramo & 2,811 & $03^{\circ} 59^{\prime} 23.2^{\prime \prime} \mathrm{S} 079^{\circ} 08^{\prime} 42.7^{\prime \prime} \mathrm{W}$ & Niemann and Behling 2008 \\
\hline El Tiro & 108 & 14620 & Páramo & 2,811 & $03^{\circ} 59^{\prime} 23.2^{\prime \prime} \mathrm{S} 079^{\circ} 08^{\prime} 42.7^{\prime \prime} \mathrm{W}$ & Niemann and Behling 2008 \\
\hline El Tiro & 125 & 23600 & Páramo & 2,817 & $03^{\circ} 59^{\prime} 23.2^{\prime \prime} \mathrm{S} 079^{\circ} 08^{\prime} 42.7^{\prime \prime} \mathrm{W}$ & Niemann and Behling 2008 \\
\hline Laguna Natosas & 40 & $\sim 2000$ & Páramo & 3,482 & $04^{\circ} 43^{\prime} 56.6^{\prime \prime} \mathrm{S} 079^{\circ} 25^{\prime} 41.2^{\prime \prime} \mathrm{W}$ & Villota et al. unpubl. \\
\hline Laguna Natosas & 140 & $\sim 9000$ & Páramo & 3,482 & $04^{\circ} 43^{\prime} 56.6^{\prime \prime} \mathrm{S} 079^{\circ} 25^{\prime} 41.2^{\prime \prime} \mathrm{W}$ & Villota et al. unpubl. \\
\hline
\end{tabular}

measurement procedure and essential specific characteristics of pollen grains of single Poaceae species.

\section{Measurement setting}

Prior to ensuing measurements leading to a differentiation between grass grain size distributions, we established how many grains had to be measured to get a representative result for the average grain length per sample. Therefore, we observed the stability of the average grain length within one sample with an increasing number of measured pollen grains. This was done for all 20 samples, which were later pooled for further analyses. Since not all grain size distributions showed a Gaussian distribution, the average grain length is given by the median. The following equations were used to calculate the development of the median grain length with increasing numbers of measured pollen grains:

$$
\begin{gathered}
X_{\text {med }}=\frac{\sum_{1}^{n} X_{n / 2+1}}{n} \text { for all odd } n \\
X_{\text {med }}=\frac{\sum_{1}^{n} 1 / 2\left(X_{n / 2}+X_{n / 2+1}\right)}{n}
\end{gathered}
$$

for all even $n$ with $n=$ number of measured grains
For the measuring procedure we mounted samples in viscous glycerine. Despite the fact that this mounting medium is known to slightly alter grain size, we applied it since it is widely used for fossil pollen that has to remain mobile. This method was standardized for all investigated samples; therefore, the deviation of size is comparable within the data set. In order to minimize the alteration of pollen grain size, on the slide all samples were measured on the same day that they were mounted in glycerine (Mäkelä 1996; Moore et al. 1991).

For all attribute measurements we aimed at an optical section view for consistent attribute ratios as can be seen in Fig. 2. For all measurements we used a Leica Photo Microscope and the accompanying image analysis software Leica QWin. We measured to the nearest $0.01 \mu \mathrm{m}$ under $400 \times$ magnification. For each pollen grain we measured a series of attributes $(\mu \mathrm{m})$ (Tweedle et al. 2005):

(1) The pollen grain length (PL) as the longest axis of the grain

(2) The pollen grain width (PW) as the axis of the grain at $90^{\circ}$ to the longest axis

(3) The pore diameter (PD) referring to the total pore diameter excluding the annulus 


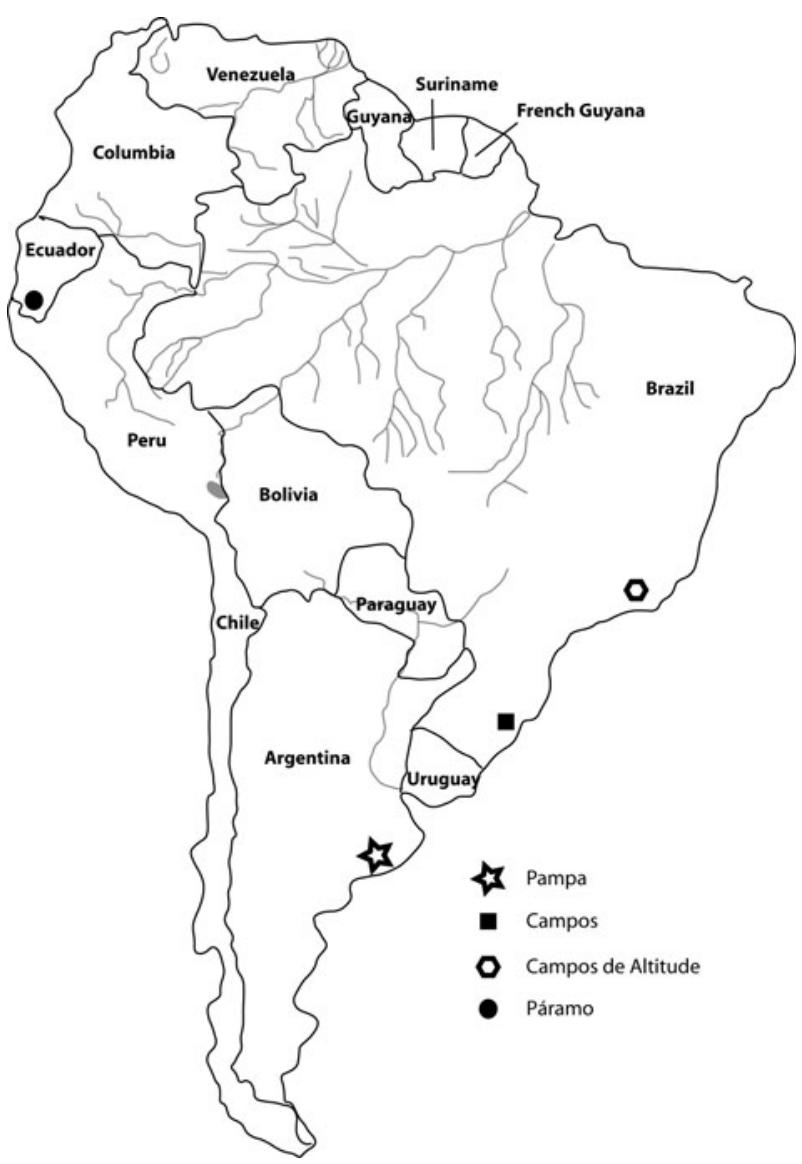

Fig. 1 Map showing the study sites within the grasslands of South America. Symbols represent the grassland ecosystems investigated

(4) The annulus width (AW) as the distance from the outline of the pore to the outline of the annulus.

The pore of Poaceae pollen grains is not always located at the distal pole, which makes it difficult to pinpoint the exact polar axis (Fægri 1978). In this study for practical purposes we measured the longest axis of the grain, which therefore does not necessarily represent the polar axis and does not always pass through the centre of the pore. However, from personal observations within our investigation we got the impression that the Poaceae grains may crumple, but they do not tend to change their shape from spheroidal to prolate, or the position of the pore within this shape due to sample preparation or mounting procedure (Beug 2004; Erdtmann 1943; Punt et al. 2007). Strongly crumpled grains were excluded from measurements.

\section{Effect of chemical treatment on grain size}

We considered it useful to investigate the impact of hydrofluoric acid (HF) on pollen grain size, as this might be an important factor to ensure data comparability. For this we used modern grass pollen of Melica nutans, Milium effusum, Koeleria macrantha and Stipa pulcherima (except

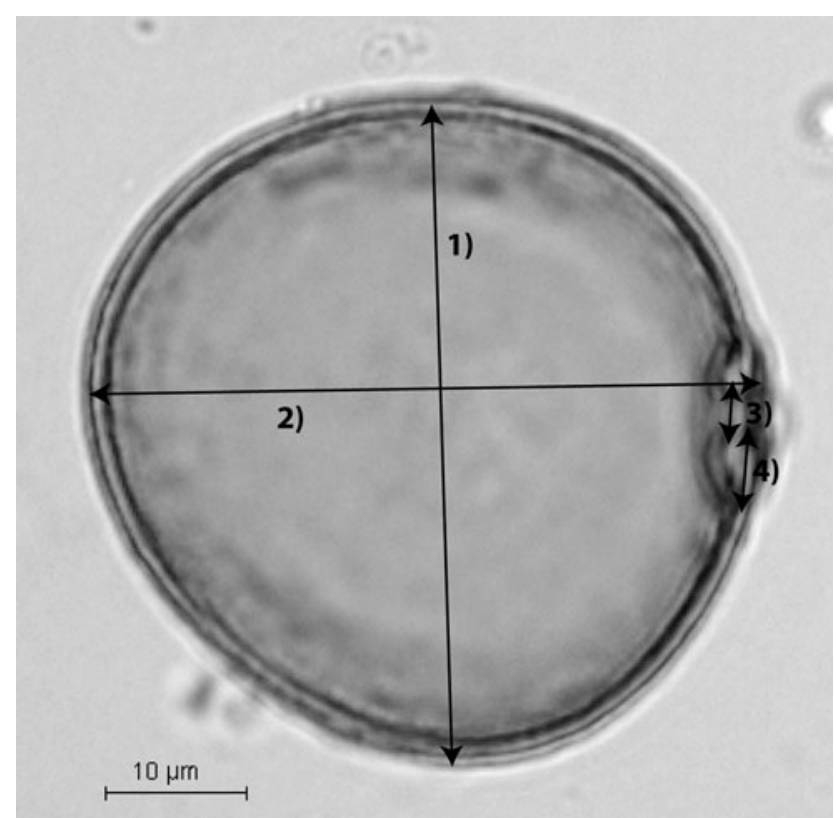

Fig. 2 Measured parameters of each Poaceae pollen grain: 1 grain length, 2 grain width, 3 pore diameter, 4 annulus width

for Milium, all genera also have neotropical species (Watson and Dallwitz 1992)). The preparation of samples was done according to an adjusted version of the standard method by Fægri and Iversen (1989). One batch of pollen of all four species was exposed to application of $10 \%$ hydrochloric acid $(\mathrm{HCl}), 75 \% \mathrm{HF}(24 \mathrm{~h})$ and acetolysis (8 min in a water bath at $90^{\circ} \mathrm{C}$ ) and the other batch was exposed only to treatment with $10 \% \mathrm{HCl}$ and acetolysis. Subsequently, all samples were given three washes in distilled water, centrifuging at $3,500 \mathrm{rpm}$ each time. Finally, we transferred the material into small tubes with distilled water where they were kept until measurement. The length of 60 pollen grains per treatment and species was measured. We compared the data sets applying statistical tests in the program $\mathrm{R}$ (The $\mathrm{R}$ Foundation for Statistical Computing 2008). With the SHAPIRO-test we tested whether our data sets were normally distributed. If this was the case, we subsequently applied an $F$-test to test the variances and lastly we ran a Student $t$-test to compare the mean of grain length. If the data set did not show a normal distribution we applied the WILCOXON-test (also known as $U$-Test) for differences in mean grain length.

Development of method for distinguishing between grassland ecosystems

\section{Sample preparation and measurements}

For size analysis of pollen grains it is essential that all samples are subjected to identical chemical and physical 
treatment. For preparation of samples, we applied the same method as for the investigation of chemical treatment on grain size mentioned above. In order to minimize the alteration of pollen grain size on the slide all samples were measured on the same day as they were mounted in glycerine (Mäkelä 1996; Moore et al. 1991). For all pollen grains the same four attributes were measured as mentioned above: pollen grain length (PL), pollen grain width $(\mathrm{PW})$, pore diameter (PD) and annulus width (AW).

In order to achieve a representative number of pollen grains per sample and hence a characteristic mean of grain length, we measured at least 60 to 80 pollen grains per sample. The pollen grains were chosen by scanning the slide from the centre to the margin. In case a slide did not provide enough grains the procedure was repeated with another slide of the same sample until the required number of grains was achieved. Heavily crumpled grains that could not be measured precisely were excluded. However, the number of excluded grains was kept as low as possible.

\section{Average pollen grain length}

Since we expected to find significant differences between average pollen grain lengths in samples from different grassland ecosystems, samples of each grassland ecosystem were pooled for this analysis. A Shapiro-Test revealed that the $p$-value for normal distribution is low ( $p$-value $<0.01)$ in all pooled data sets. Hence for a comparison we used the median of the pollen grain length. We applied a Kruskal-Wallis Rank Sum Test to test for differences between the grassland ecosystems with respect to their grain size distribution and median. Subsequently, we applied a Pairwise Wilcoxon Rank Sum Test as a post-hoc test. A Holm correction for adjustment of the alpha levels was applied.

\section{Multivariate data analysis_principal component analysis}

PCA was used as an indirect linear ordination technique of all samples using all attained grain parameters. For all computations the program Canoco (ter Braak and Smilauer 1997) was used. Our data sets were standardized and centred (by species) to allow comparison between parameters. No data transformation was conducted.

\section{Multivariate data analysis-trait-convergence and trait divergence assembly patterns by pollen grain classification}

This approach follows the method of trait-convergence and trait-divergence assembly patterns by Pillar and Sosinksi (2003) and Pillar et al. (2009) (Fig. 3). Instead of plant functional types our approach uses pollen grain types. Communities as described by Pillar correspond to our samples. The investigated sites cannot be classified as communities since we do not know whether the pollen grain type composition was constant over time, therefore the samples were used instead. The term "pollen grain parameter" is used as a synonym for "trait" as used by Pillar and Sosinksi (2003) and Pillar et al. (2009).

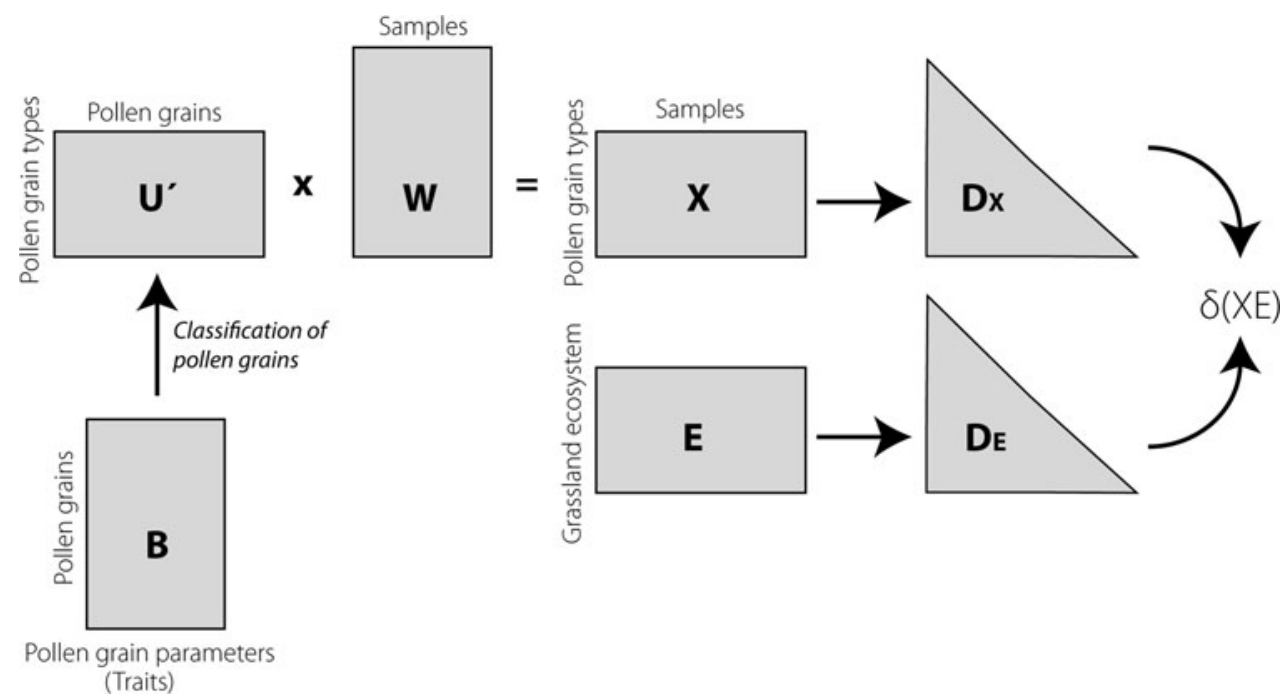

Fig. 3 The chart shows the procedure of trait-convergence and traitdivergence assembly patterns (TCAP/TDAP) The correlation $\delta \mathrm{XE}$ between the dissimilarity matrices DX and DE is calculated according to Pillar and Sosinksi (2003). The three data matrices needed are B, which describes the pollen grains by pollen grain parameters (traits), $\mathrm{U}^{\prime}$ contains degrees of belonging of pollen grains to pollen grain types defined by pollen grain parameters and $\mathrm{W}$, which describes samples by presence or absence of pollen grain types. In matrix E samples are assigned to a certain grassland ecosystem and matrix $\mathrm{X}=\mathrm{U}^{\prime} \times \mathrm{W}$. DX and DE represent the dissimilarity matrices of $\mathrm{X}$ and $\mathrm{E}$. $\delta \mathrm{XE}$ is the correlation matrix between DX and DE 
For the analysis the data is organized in matrices: Matrix B describes the individual pollen grains by pollen grain parameters, matrix $U^{\prime}$ describes the degree of belonging of a pollen grain to a pollen grain type, and matrix $\mathrm{W}$ describes the samples by the presence or absence of pollen grain types. In matrix $\mathrm{E}$ samples are assigned to a certain grassland ecosystem and matrix $\mathrm{X}$ is computed by $\mathrm{U}^{\prime} \times \mathrm{W}$. DX and DE represent the dissimilarity matrices of $\mathrm{X}$ and $\mathrm{E}$. $\delta \mathrm{XE}$ is the correlation matrix between DX and DE. The pollen grain parameters are the pollen grain length and width, the pore diameter and the annulus width. The samples considered are listed in Table 1, and the associated grassland ecosystems are Páramo in southern Ecuador, Campos and Campos de Altitude in southeastern and southern Brazil, and the Pampas in Argentina.

For the analysis the program SYNCSA was used, developed by Pillar et al. (2009) especially for this kind of analysis. In order to analyze trait-convergence (TCAP) and trait-divergence assembly patterns (TDAP) in the data set, it is necessary to define pollen grain types based on the available traits. Once the three above mentioned matrices are loaded into SYNCSA the character ranking settings are defined. In our analysis we used TCAP and TDAP for maximization of trait ranking criteria.

For retrieving pollen grain types, several settings had to be chosen in SYNCSA (Table 2).

The program filters combinations of traits and the number of determined pollen grain types for the highest correlation between matrices B, W and E. Upon determination of the number of pollen grain types the data structure of the sites is explored. For this analysis the traits, which in combination obtained the highest number of pollen grain types as well as a high correlation value, are used.

The trait subsets given are optimal for each level starting with one trait, followed by the corresponding optimal

Table 2 Settings for the calculation of pollen types in SYNCSA

\begin{tabular}{ll}
\hline Clustering Method & Average Linking (UPGMA) \\
\hline $\begin{array}{c}\text { Resemblance measure } \\
\text { between pollen grains }\end{array}$ & $\begin{array}{c}\text { Gower Index (for standardization } \\
\text { of matrix) } \\
\text { Crisp option (one pollen grain } \\
\text { assigned to one type) }\end{array}$ \\
$\begin{array}{l}\text { Number of parameters (traits) } \\
\text { used }\end{array}$ & All available parameters \\
$\begin{array}{l}\text { Resemblance measure for } \\
\text { parameter (trait) subset }\end{array}$ & Chord distance \\
optimization & \\
$\begin{array}{c}\text { Boundary conditions } \\
\text { for TCAP and TDAP }\end{array}$ & Min. number of pollen types: \\
& 2, max. number of pollen types: \\
\hline
\end{tabular}

Table 3 Results of the analysis of parameter (trait) subsets

\begin{tabular}{lll}
\hline Parameter & No. of pollen grain types & $\delta_{\mathrm{XE}}$ \\
\hline PW & 5 & 0.55 \\
PW, PD & 42 & 0.52 \\
PL, PW, AW & 2 & 0.57 \\
PL, PW, PD, AW & 5 & 0.44 \\
\hline
\end{tabular}

Pollen grain parameters and their corresponding number of derived groups as well as the matrix correlation $(\delta \mathrm{XE})$ between $\mathrm{DX}$ and $\mathrm{DE}$ are given

number of groups and ranking criterion values for the optimal subsets (Table 3).

It is inevitable for the analysis that the combination of correlation values between matrices and number of pollen grain types are high. If either of them shows a value that is too low, a retrieval of inherent patterns through ordination is unlikely. The trait-based approach is based on the composition of types.

The clustering method for defining the types was the Unweighted Pair Group Method with Arithmetic Mean (UPGMA). The resemblance function between individual pollen grains based on the traits was the Gower Index.

The number of examined types was set to 42 according to the results from the trait-subset optimization. Resemblance between sites was measured by the chord distance.

Subsequently, two Principal Coordinate Analyses (PCoA) were performed with the program MULTIV. The first data set included the 42 pollen grain types and the trait subset of pollen grain width (PW) and pore diameter (PD). The second data set which was subject to a PCoA contained the samples based on the composition of pollen grain types.

\section{Results}

Results of the preparatory investigations

\section{Measurement setting}

Figure 4 shows that the average grain length (given as median) still varies a lot within the first 30-35 measured pollen grains of a sample. However, it stabilizes after 40-45 pollen grains. Above this number the median remains stable with a variation between 0.1 and $1 \mu \mathrm{m}$.

\section{Effect of chemical treatment on grain size in preparation procedure}

Our tests on the impact of different preparation methods have shown that pollen grain size differs significantly 
Fig. 4 Evolution of average Poaceae pollen grain length Xn (given as median) with increasing number of measured grains $n$

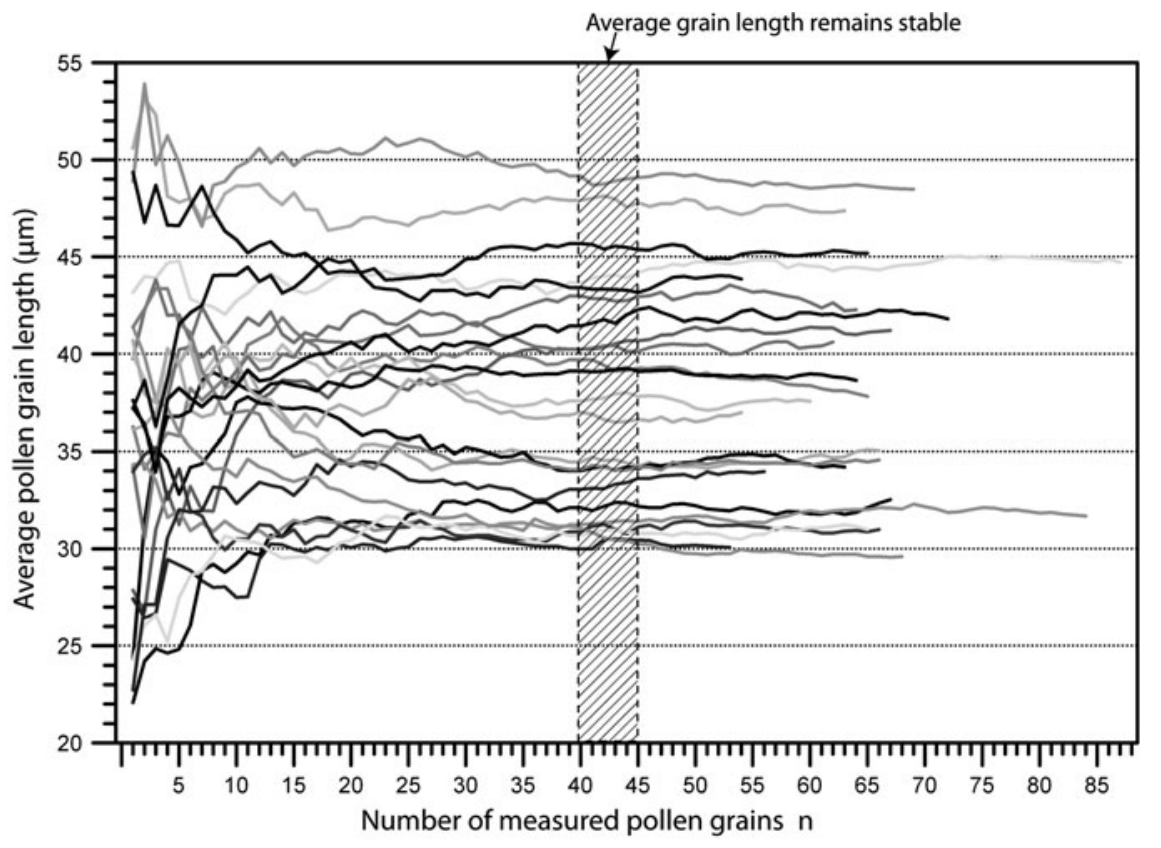

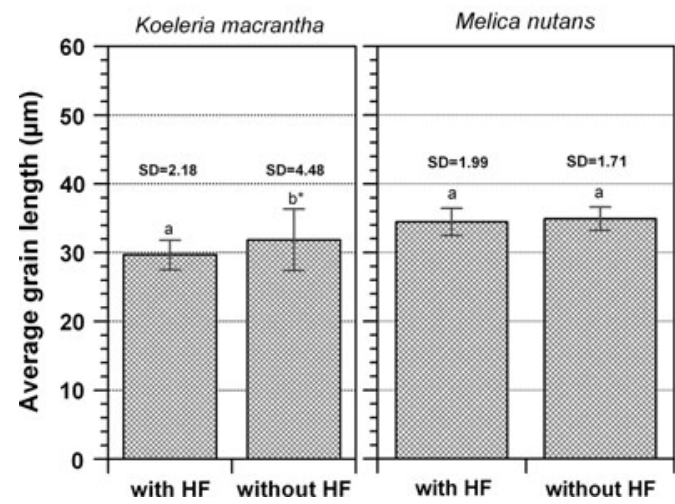
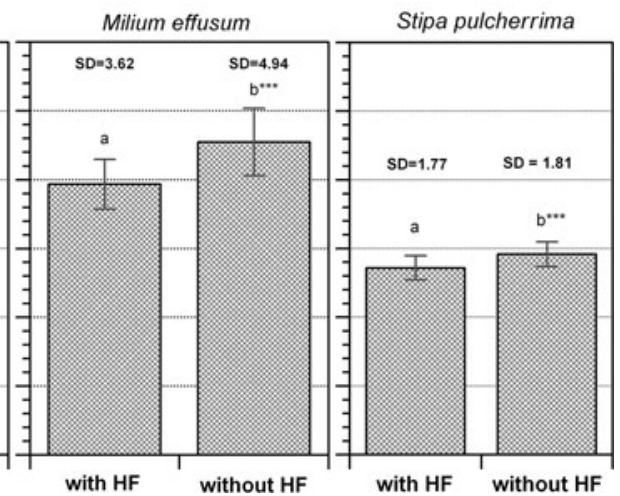

Fig. 5 Comparison of pollen grain samples subject to chemical treatment with and without hydrofluoric acid (HF) of four different Poaceae species. Statistical analyses ( $T$-test and Wilcoxon Test) were applied to the pollen grain length for comparison between different

preparation methods. The results revealed differences in pollen grain length at different levels of significance as marked by $*=(p<0.05)$ and $* * *=(p<0.001)$. The standard deviation (SD) of the pollen grain length is given for each species and preparation method

between samples treated with and without HF for the species Milium effusum, Stipa pulcherima $(p<0.1)$ and Koeleria macrantha $(p<0.001)$ (Fig. 5). In case of the species Melica nutans no significant differences could be observed $(p<0.2333)$. The pollen grains of Milium effusum treated with $\mathrm{HF}$ are on average $6.12 \mu \mathrm{m}$ smaller ( $\triangleq 13.48 \%$ of HF untreated grain length). Pollen grains of Koeleria macrantha treated with HF are smaller compared to the ones treated without HF by $2.19 \mu \mathrm{m}(\bumpeq 6.87 \%)$. Melica nutans pollen grains display a length difference of only $0.47 \mu \mathrm{m}(\hat{=} 1.35 \%)$ between the two treatments which is not significant. Finally, Stipa pulcherima pollen grains treated with $\mathrm{HF}$ are $1.98 \mu \mathrm{m}$ smaller than untreated grains which is a highly significant result. The standard deviations (SD) are very similar in the case of Melica nutans and Stipa

pulcherima (1.99 and 1.71, and 1.77 and $1.81 \mu \mathrm{m}$ respectively). The standard deviation values for Koeleria macrantha (2.18 and $4.48 \mu \mathrm{m})$ and Milium effusum (3.62 and $4.94 \mu \mathrm{m})$ are larger.

Results from the developed method

The data sets of the different grassland ecosystems show different pollen grain size ranges (Fig. 6). The Páramo data set has the largest pollen grains over all and also on average (median: $43.56 \mu \mathrm{m}$ ). The variation of grain size is rather high ranging from 65.73 to $17.18 \mu \mathrm{m}$ as shown by the single outlier value of this data set. The median value of $31.71 \mu \mathrm{m}$ for the Campos pollen grains is considerably smaller compared to Páramo. The pollen grain size ranges 


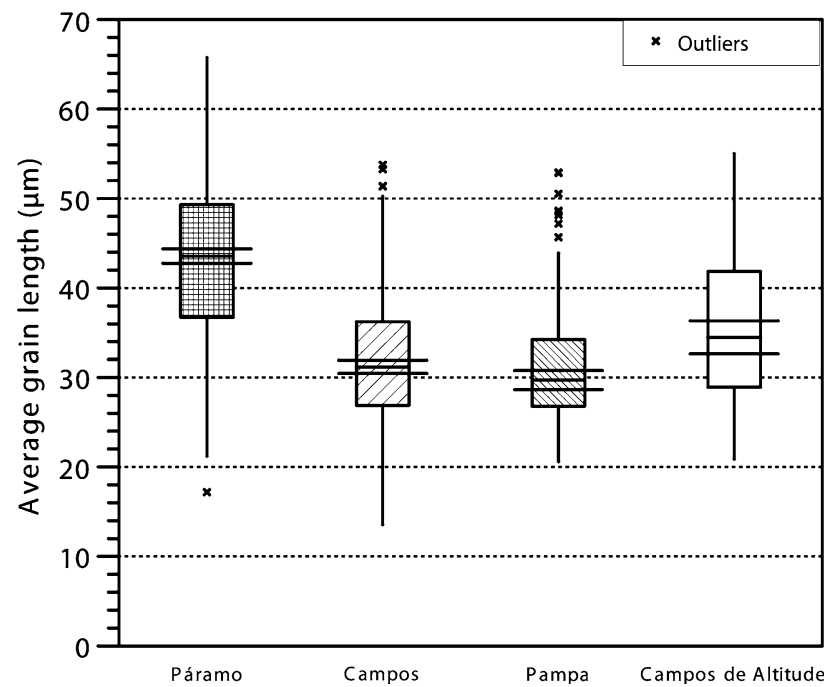

Fig. 6 The box and whisker plot shows the differences in average Poaceae pollen grain length between the grassland ecosystems and the variability within one grassland ecosystem. All differences are highly significant as marked by $* * *=(p<0.001)$. The central horizontal line marks the median, the lines above and below mark the notches (median $\pm 1.58 / \sqrt{ } \mathrm{n}$ ). The box comprises $50 \%$ of the values (upper and the lower $25 \%$ quartile around the median). The whiskers represent the $75 \%$ quartiles. Measured values larger than the upper quartile $+1.5^{*}$ quartile distance are plotted as 'outliers'. The quartile distance is the distance between the box and the end of the whisker (75\% quartile)

from 13.56 to $53.76 \mu \mathrm{m}$, the latter being accounted for by three outlying values. The Pampa box plot assumes a position similar to the one of the Campos. However, the median value is lower $(29.70 \mu \mathrm{m})$ despite the size range being distinctively smaller compared to Campos at the lower end of the scale. The upper limit (max: $52.91 \mu \mathrm{m}$ ) is again very similar to the one seen in the Campos data set, although the largest grains have outlier values. The $50 \%$ range of this data set is very narrow when compared to the other data sets. The grain size distribution of the Campos de Altitude data set assumes an intermediate position on the size scale which is also displayed by the median value $(34.45 \mu \mathrm{m})$. The largest grain size found was $55.02 \mu \mathrm{m}$, the smallest $17.18 \mu \mathrm{m}$. This box plot shows no outlying values and the 50\% range is rather broad. A very broad 50\% size range is also depicted in the Páramo box plot.

The comparison of the pooled datasets of the different grassland ecosystems applying a Kruskal-Wallis-Test revealed that not all differences between pollen grain length of Páramo, Campos, Campos de Altitude and Pampa were significant $(p<0.2)$.

A Pairwise-Wilcoxon-Rank-Sum-Test as a post-hoc test (Holm adjusted) showed that only the differences between Campos and Pampa data sets are not significant (Table 4). All other data sets from the different grassland ecosystems show highly significant differences among one another.
Table 4 Probabilities of differences between grassland ecosystems as given by the post-hoc Pairwise Wilcoxon Rank Sum Test

\begin{tabular}{llll}
\hline Site & Campos & Campos de Altitude & Pampa \\
Campos de Altitude & $4.4 \mathrm{e}-05$ & - & - \\
Pampa & 0.21 & $4.4 \mathrm{e}-05$ & - \\
Páramo & $<2 \mathrm{e}-16$ & $8.0 \mathrm{e}-15$ & $<2 \mathrm{e}-16$ \\
\hline
\end{tabular}

Multivariate data analysis-principal component analysis of pollen grain parameters

Figure 7 shows the result of the Principal Component Analysis (PCA) performed with all obtained pollen grain parameters of the four grassland ecosystems. The parameters pollen grain length (PL), pollen grain width (PW) and pore diameter (PD) correlate most strongly with the first ordination axis whereas the annulus width (AW) correlates more with the second ordination axis. The former three also correlate strongly with each other. The parameters explaining most of the variability on the first PCA axis are PL, PW and PD, all of them with a similar influence on the distribution of the data set within the ordination space. The envelopes (connecting the extreme values) applied to the data sets which belong each grassland ecosystem illustrate their distribution. The Páramo markers clearly dominate the first and the fourth quadrant of the ordination space. They also show the widest range; especially noticeable is their extent into the right hand side. In contrast, the concentration of markers representing the Campos is more shifted into the two quadrants on the left of the diagram (quadrants two and three). The range of the Campos markers is slightly smaller in size compared to the Páramo but larger than the other two. The Campos de Altitude markers assume a central position and comprise a small diagram space. The concentration of markers is highest in the second and third quadrants. Only a few markers dictate the extent of the envelope into the first and fourth quadrants of the diagram. The Pampa markers again clearly dominate in quadrants two and three; hence, they are fully included among the markers representing the Campos and to a great part also among those representing the Campos de Altitude.

\section{Multivariate data analysis - trait-convergence and trait-divergence assembly patterns by pollen grain classification}

The PCoA diagram (Fig. 8a) of the 20 samples (representing samples differing in location as well as in age) shows that the different grassland ecosystems can be retrieved from the composition of pollen grain types. The Campos markers, as well as those for the Pampa and the Campos de Altitude are clearly located in the left side of the ordination space, whereas the Páramo is distributed 


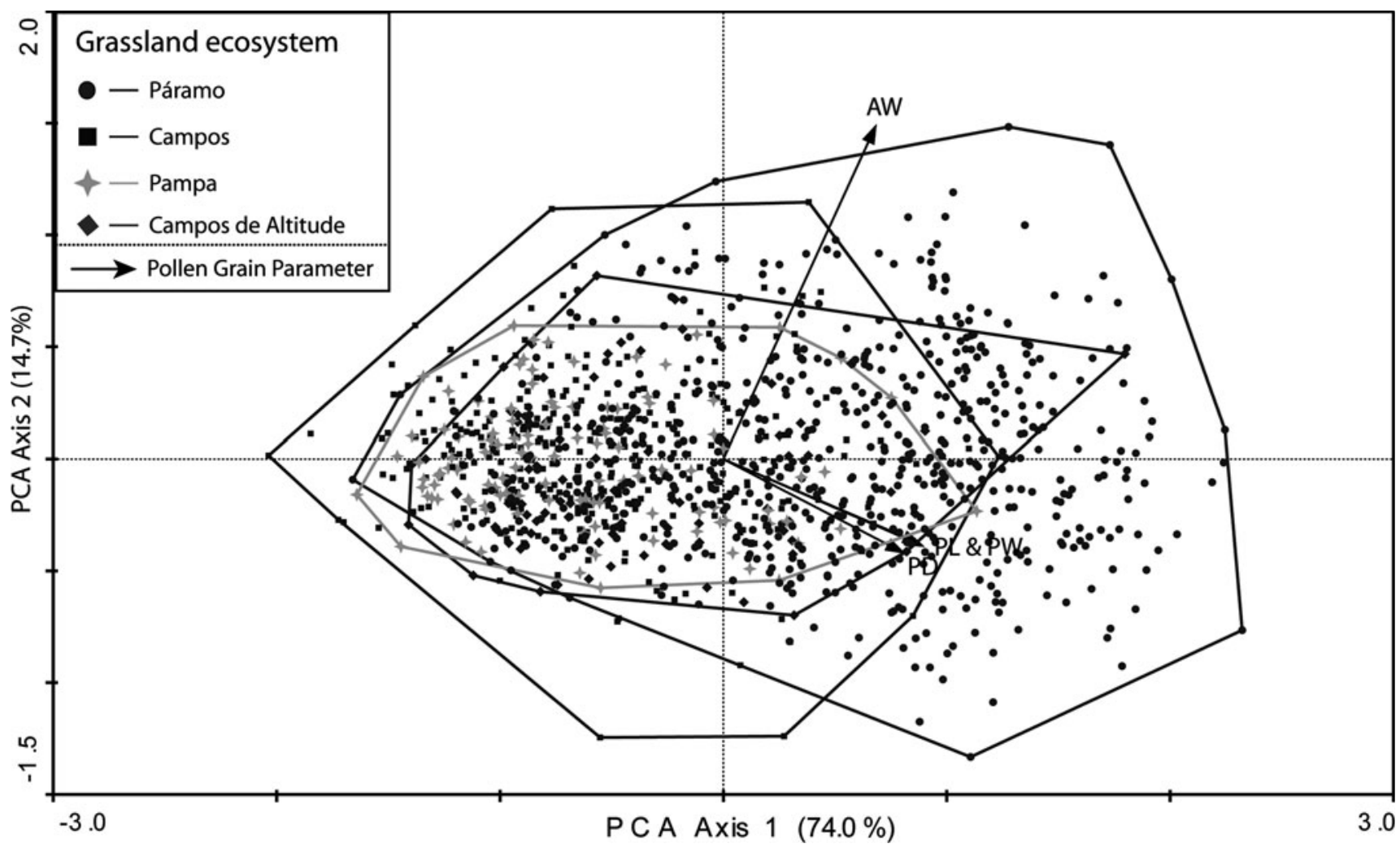

Fig. 7 Diagram shows the results of a Principal Component Analysis (PCA) performed with the all measured Poaceae pollen grain parameters of samples from all grassland ecosystems. $P L$ pollen grain length, $P W$ pollen grain width, $P D$ pore diameter, $A W$ annulus width. The envelopes show the outline of markers representing the extreme values of each data set (a)

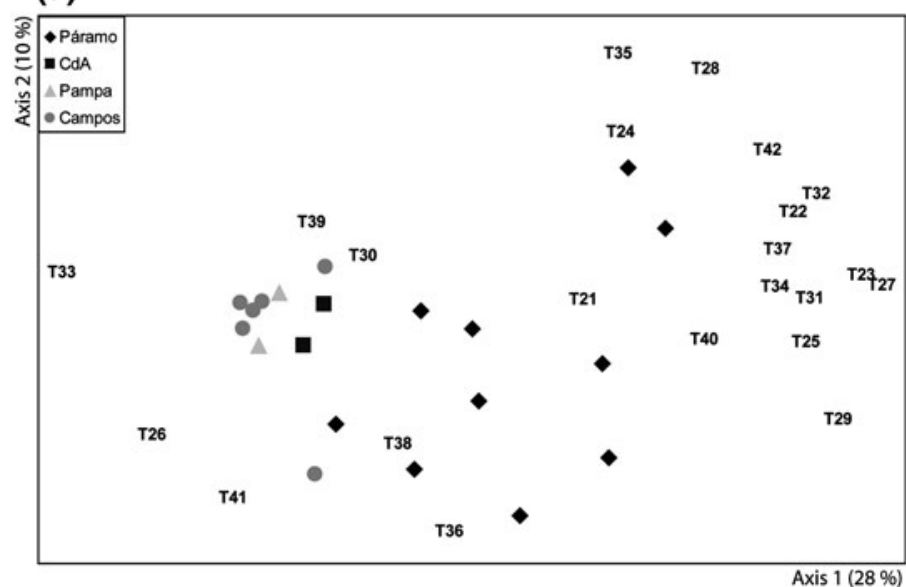

(b)

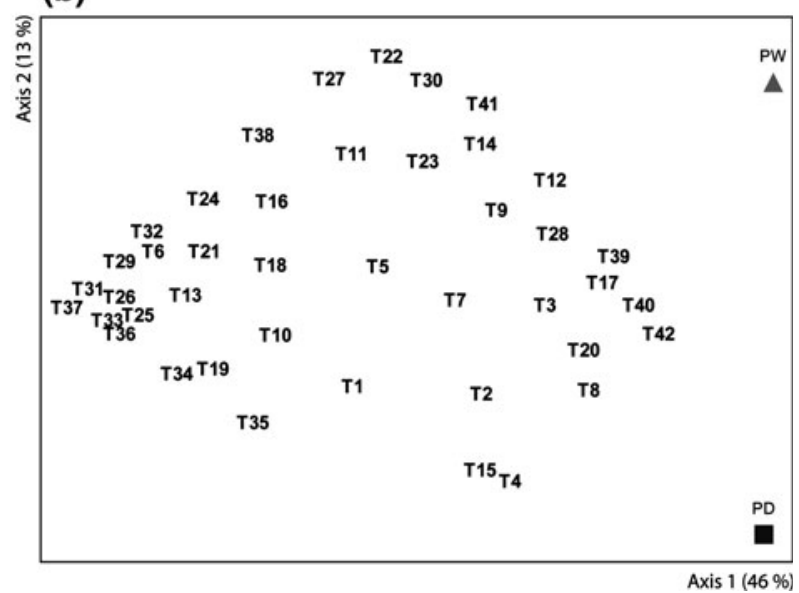

Fig. 8 a Principle Coordinate Analysis (PCoA) of the samples based on the pollen grain types (highly correlated pollen grain types are also shown) b PCoA of the pollen grain types defined by optimal parameter subset (parameters are plotted based on correlation with axes)

more to the right. The position of the first three grassland ecosystems is determined by the presence of pollen grain types T33, T26, T30 and T39, whereas the location of the Páramo markers is determined by the presence of the pollen grain types T42, T40, T25, T34 and T31 (on the first axis).
The PCoA diagram (Fig. 8b) of the 42 pollen grain types based on the trait subset PW and PD shows that types located closer to the trait markers of PW and PD represent wider pollen grains, and grains with a larger pore diameter, respectively. Since pollen grain width as well as pore diameter is strongly correlated with the pollen grain length, 
a general increase of pollen grain size can be assumed for pollen grain types closer to the trait markers.

\section{Discussion}

The analysis of changes in median with an increasing number of measured pollen grains has shown that the median grain length per sample remains stable after 40-45 measured pollen grains. This, of course, is very important when trying to compare data sets from different locations and different periods. The median is certainly a very rough measure for an investigation of differences in pollen grain length and their composition, but it serves well as a first approach to get an impression on the data we have obtained from our samples. Despite the stabilization of the median value from 45 measured pollen grains or more, we recommend measuring at least 60 pollen grains for each sample to be completely sure about the representation of the median for the data set.

Chemical treatment of pollen grains obviously has an effect on the pollen grain length, but this effect seems to differ among species. Hence, within the scope of our developed method, these results confirm that it is very important to standardize the sample preparation to avoid alteration of grain size due to differences in the pollen grain treatment.

The average pollen grain length per data set demonstrates that there are significant differences between the different grassland ecosystems except between the Campos and Pampa. Since pollen grains of one species show different ranges of variation in grain size (Joly et al. 2007), we cannot directly relate certain grain sizes to a certain genus or species. Nevertheless, the variation within neo-tropical species was found to be rather low as shown by Joly et al. (2007). Due to this circumstance and the observation of evident differences between the grassland ecosystems, we assume differences in grass taxa composition to be causing this phenomenon. The high variation of grain sizes in the data set for a single grassland ecosystem is surely also due to differences between sample location and sample age, which were pooled for this analysis. The former applies for samples from the Páramo, Campos de Altitude and Pampa; the latter for samples from all grassland data sets.

Assuming that a grain size range can be assigned to certain grass taxa, without being able to be specific in this respect, we should be able to draw conclusions about development and dynamics of grasslands over time, as well as possible common origins in the case of geographically close grassland ecosystems such as Pampa and Campos, and Campos de Altitude, respectively. Furthermore, our method could be used to give a more detailed insight into the yet unsolved issue of the origin of the Campos, which is still debated (Behling et al. 2004).

The results of the PCA give an interesting view on the data set. Since in this analysis all parameters were included, the derived patterns are most realistic. This is especially the case for the patterns along the abscissa, as this axis explains a very high percentage of variability within the data set. A strong correlation between pollen grain length, grain width and pore diameter can be noted. In earlier studies on Poaceae pollen grain size a correlation between pollen grain length (longest axis) and pollen grain width (axis orthogonal to previous mentioned axis) has already been shown in Avena sativa (Katsiotis and Forsberg 1995). Our results confirm this observation.

The area of highest marker concentration as well as the marker range within the ordination space allows distinction between the different grassland ecosystems. The results concerning the distribution of pollen grain size amongst the different grassland ecosystems coincide with these derived from TCAP/TDAP approach. This outcome of the multivariate data analysis gives evidence that differences in Poaceae taxa composition are reflected in different pollen grain size compositions. This again enables us to distinguish clearly between the grassland ecosystems without information on which Poaceae taxa create this pattern. However, the pooling of samples from one grassland ecosystem definitely adds to the noise in the ordination diagram. In addition, analysis of more samples would refine the patterns found.

The second approach based on trait-convergence and trait-divergence shows that a distinction between grassland ecosystems is possible even when applying an intermediate step of pollen grain classification into pollen grain types. Páramo grasslands are predominantly characterized by mainly large pollen grains. The other three grassland ecosystems are described by types representing smaller pollen grains. The results are concordant with the PCA results in which we can also show that the Páramo grasslands are characterized by larger pollen grains whereas Pampa and Campos can be identified by especially small pollen grains.

The method established by Pillar et al. (2009) already assumes a pattern associated with the different grassland ecosystems since the computation of matrices requires an allocation of pollen grains to a grassland ecosystem and a sample. Hence, this method has the potential to clarify existing patterns, but not so much for exploring unknown patterns. Meanwhile, the method of applying PCA directly to the pollen grains does not imply certain patterns and therefore displays fairly unbiased results.

Since our approach is explorative, it should be preferred for the analysis of palaeograsslands by means of Poaceae pollen grains. The fact that the well-established method of 
Pillar and Sosinksi (2003) and Pillar et al. (2009) reveals the same results validates the outcome of our method.

This study shows that a distinction between South American grassland ecosystems is possible. We believe that this approach has high potential for unravelling so far inaccessible patterns and dynamics of biodiversity and taxa composition of palaeograsslands. Further, when applied to fossil records, this method will allow the detection of shifts in biomes and in vegetation composition.

The next step is to apply this method to samples within one grassland type to investigate spatial and temporal patterns and compare them to existing data on palaeograssland dynamics in order to verify our results.

We are aware of the fact that the number of samples used to establish this method is rather low. Hence the results have to be confirmed with additional measurements from surface samples to allow comparison with present vegetation, from samples of the same grassland types from different locations, and further grassland types present in South America such as Llanos Orientales, Orinoco Llanos, Puna, Guianan savannas, Amazonian savannas, Cerrado and the Patagonian steppe.

For further studies dealing with dynamics of one grassland type, we will have a closer look at size distribution of samples from one location but of different ages. Especially interesting should be samples from before and after the Last Glacial Maximum, the last interglacial Eemian as well as the late Holocene period, which have surely also caused substantial species turnover in grassland ecosystems.

\section{Conclusion}

In our study, we demonstrate that a distinction between grassland ecosystems based on measurable Poaceae pollen grain parameters is possible. This becomes most evident when using the pollen grain length for the analysis and multivariate data analysis. The statistical tests applied reveal significant differences between average grain lengths of the four grassland ecosystems. Two independent multivariate approaches were applied and both showed the same patterns, which validates the outcome. Pollen grain size composition as well as pollen grain size range can be used to distinguish between, and define all, investigated palaeograssland types in South America.

In contrast to studies investigating ornamentation of pollen grains, which would possibly give more insight into differentiation between taxa, this method is convenient and feasible while counting pollen slides under $400 \times$ magnification. This aspect is especially important since the assignment of grassland samples to a grassland type will be a side effect rather than requiring a time-consuming additional study.
To continue this work, more samples on a large spatial scale will have to be investigated to define general trends in South American grassland ecosystems. We will also perform analyses on a smaller scale within one grassland ecosystem in order to investigate temporal and spatial patterns leading to information on palaeo-grassland dynamics. We think that this method yields high potential for giving access to so far inaccessible information on spatial and temporal patterns and dynamics of South American grasslands.

Acknowledgments We would like to thank Valério DePatta Pillar for advice and support with his program. Special thanks also go to Andree Ehlert and Jürgen Kluge for their support with the statistics. Petra Lembcke helped with measuring the many pollen grains. We appreciated the discussions with Frank Schlütz and Thomas Giesecke on various aspects of this manuscript. We would also like to thank Mark Bush and William Gosling for constructive comments. Thanks to Anne-Birgitte Nielsen for English language assistance.

Open Access This article is distributed under the terms of the Creative Commons Attribution Noncommercial License which permits any noncommercial use, distribution, and reproduction in any medium, provided the original author(s) and source are credited.

\section{References}

Alexandre A, Meunier J-D, Lézine AM, Schwartz D (1997) Phytolihts: indicators of grassland dynamics during the late Holocene in the intertropical Africa. Palaeogeogr Palaeoclimatol Palaeoecol 136:213-229

Alves RJV, Kolbek J (1994) Plant species endemism in savanna vegetation on table mountains (Campos Rupestre) in Brazil. Vegetatio 113:125-139

Amundson R, Evett RR, Jahren AH, Bartolome J (1997) Stable carbon isotope composition of Poaceae pollen and its potential in paleovegetational reconstruction. Rev Palaeobot Palynol 99:17-24

Andersen ST (1979) Identification of wild grass and cereal pollen. Danmarks Geol Undersøgelse Årbog 1978:69-92

Behling H (2002) South and southeast Brazilian grasslands during Late Quaternary times: a synthesis. Palaeogeogr Palaeoclimatol Palaeoecol 177:19-27

Behling H, Hooghiemstra H (2001) Neotropical Savanna environments in space and time: late quaternary interhemispheric comparisions. In: Markgraf V (ed) Interhemispheric climate linkage. Elsevier, Amsterdam, pp 307-323

Behling H, Pillar VD (2008) Vegetation and fire dynamics in southern Brazil during the late Quaternary and their implication for conservation and management of modern grassland ecosystems. In: Schroder HG (ed) Grasslands: ecology, management and restoration. Nova Science Publisher, Hauppauge

Behling H, Pillar VD, Orloic L, Bauermann SG (2004) Late Quaternary Araucaria forest, grassland (Campos), fire and climate dynamics, studied by high-resolution pollen, charcoal and multivariate analysis of the Cambara do Sul core in southern Brazil. Palaeogeogr Palaeoclimatol Palaeoecol 203:277-297

Beug HJ (1961) Leitfaden der Pollenbestimmung. Fischer, Stuttgart

Beug HJ (2004) Leitfaden der Pollenbestimmung für Mitteleuropa und angrenzende Gebiete. Pfeil, München

Bolbochan D, Salgado-Labouriau ML (1983) Estiramiento de los granos de polen de Scheelea macrolepis. VII Congreso Venezolano de Botánica, Caracas 
Boldrini II (2009) A flora dos camposdo Rio Grande do Sul. In: Pillar VD, Müller SC, Souza Castillo ZM, de Ávila J, Aino V (eds) Campos Sulinos-conservação e uso sustentável da biodiversidade. Ministério do Meio Ambiente, Brasilia/DF

Brunschön C, Behling H (2009) Late Quaternary vegetation, fire and climate history reconstructed from two cores at Cerro Toledo, Podocarpus National Park, southeastern Ecuadorian Andes. Quat Res 72:388-399

Cushing EJ (1961) Size increase in pollen grains mounted in thin slides. Pollen Spores 3:265-274

Danzeglocke U, Jöris O, Weninger B (2009) CalPal-2007 ${ }^{\text {online }}$. http://www.calpal-online.de/. Accessed 17 July 2009

Dickson C (1988) Distinguishing cereal from wild grass pollen: some limitations. Circaea 5:67-71

Erdtmann G (1943) Introduction into pollen analysis. Chronica Botanica Co, Waltham, MA

Fægri K (1978) What is the polar axis? Grana 17:15-16

Fægri K, Iversen J (1989) Textbook of pollen analysis. Wiley, Chichester

Fernandéz Honaine M, Zucol AF, Osterrieth ML (2006) Phytolith assemblages and systematic associations in grassland species of the South-Eastern Pampean Plains, Argentina. Ann Bot 98:1,1551,165

Fernandéz Honaine M, Osterrieth ML, Zucol AF (2009) Plant communities and soil phytolith assemblages relationship in native grasslands from southeastern Buenos Aires province, Argentina. Catena 76:89-96

Gosling WD, Mayle FE, Tate NJ, Killeen TJ (2009) Differentiation between Neotropical rainforest, dry forest, and savannah ecosystems by their modern pollen spectra and implications for the fossil pollen record. Rev Palaeobot Palynol 153:70-85

Haberle SG, Maslin MA (1999) Late Quaternary vegetation and climate change in the Amazon basin based on a 50,000 year pollen record from the Amazon fan, ODP site 932. Quat Res 51:27-38

Hamilton AC (1972) The interpretation of pollen diagram from highland Uganda. Palaeoecol Afr 7:45-149

Holst I, Moreno E, Piperno DR (2007) Identification of teosinte, maize, and Tripsacum in Mesoamerica by using pollen, starch grains, and phytoliths. PNAS 104:17,608-17,613

Iriarte J (2003) Assessing the feasibility of identifying maize through the analysis of cross-shaped size and three-dimensional morphology of phytoliths in the grasslands of southeastern South America. J Archaeol Sci 30:1,085-1,094

Iriarte J (2006) Vegetation and climate change since $14,81014 \mathrm{C}$ yr B. $\mathrm{P}$. in southeastern Urugay and implications for the rise of early formative societies. Quat Res 65:20-32

Joly C, Barille L, Barreau M, Mancheron A, Visset L (2007) Grain and annulus diameter as criteria for distinguishing pollen grains of cereals from wild grasses. Rev Palaeobot Palynol 146:221-233

Katsiotis A, Forsberg RA (1995) Pollen grain size in four ploidy levels of genus Avena. Euphytica 83:103-108

Köhler E, Lange E (1979) A contribution to distinguishing cereal from wild grass pollen grains by LM and SEM. Grana 18:133-140

Mäkelä EM (1996) Size distinction between Betula pollen types-a review. Grana 35:248-256

Meltsov V, Poska A, Saar M (2008) Pollen Size in Carex: the effect of different chemical treatments and mounting media. Grana 47:220-233

Moore PD, Webb JA (1978) An illustrated guide to pollen analysis. Halsted Press, New York

Moore PD, Webb JA, Collinson ME (1991) Pollen analysis. Blackwell, Oxford

Nelson DM, Hu FS, Michener RH (2006) Stable-carbon isotope composition of Poaceae pollen: an assessment for reconstructing C3 and C4 grass abundance. Holocene 16:819-825
Nelson DM, Hu FS, Mikucki JA, Tian J, Pearson A (2007) Carbonisotopic analysis of individual pollen grains from $\mathrm{C} 3$ and $\mathrm{C} 4$ grasses using a spooling-wire microcombustion interface. Geochimica et Cosmochimica Acta 71:4,005-4,014

Nelson DM, Hu FS, Scholes DR, Joshi N, Pearson A (2008) Using SPIRAL (Single Pollen Isotope Ratio Analysis) to estimate C3and C4-grass abundance in the paleorecord. Earth Planet Sci Lett 269:11-16

Nicora EG, Rúgulo de Agasar ZE (1987) Los géneros de gramíneas de América Austral. Buenos Aires

Niemann H, Behling H (2008) Late Quaternary vegetation, climate and fire dynamics inferred from the El Tiro record in the southeastern Ecuadorian Andes. J Quat Sci 23:203-212

Niemann H, Behling H (2010) Late Holocene environmental change and human impact inferred from three soil monoliths and the Laguna Zurita multi-proxi record in the southeastern Ecuadorian Andes. Veget Hist Archaeobot 19:1-15

Niemann H, Haberzettl T, Behling H (2009) Holocene climate variability and vegetation dynamics inferred from the $(11700 \mathrm{cal}$. yr BP Laguna Rabadilla de Vaca sediment record, southeastern Ecuadorian Andes. Holocene 19:307-316

Overbeck GE, Müller SC, Pillar VD, Pfadenhauer J (2005) Fine-scale post-fire dynamics in the southern Brazilian suptropical grassland. J Veget Sci 16:655-664

Overbeck GE, Müller SC, Fidelis A, Pfadenhauer J, Pillar VD, Blanco CC, Boldrini II, Both R, Forneck ED (2007) Brazil's neglected biome: the South Brazilian Campos, perspectives in plant ecology. Evol Syst 9:101-116

Pillar VD, Sosinksi EE (2003) An improved method for searching plant functional types by numerical analysis. J Veget Sci 14:323-332

Pillar VD, Duarte LS, Sosinksi EE, Joner F (2009) Discriminating trait-convergence and trait divergence assembly patterns in ecological community gradients. J Veget Sci 20:334-348

Prieto AR (1996) Late Quaternary vegetational and climatic changes in the pampa grassland of Argentina. Quat Res 45:73-88

Prieto AR (2000) Vegetational history of the Late glacial-Holocene transition in the grasslands of eastern Argentina. Palaeogeogr Palaeoclimatol Palaeoecol 157:167-188

Punt W, Hoen PP, Blackmore S, Nilsson S, Le Thomas A (2007) Glossary of pollen and spore terminology. Rev Palaeobot Palynol 143:1-81

Rohde E (1959) Überprüfung und Ausbau der Getreide-Pollenanalyse. Dissertation, University of Göttingen

Roubik DW, Moreno JE (1991) Pollen and spores of Barro Colorado Isand. Missouri Botanical Garden, Missouri

Salgado-Labouriau ML, Rinaldi M (1990a) Measurements of Gramineae pollen of the Venezuelan mountains. Rev Brasil Biol 50:115-122

Salgado-Labouriau ML, Rinaldi M (1990b) Palynology of Gramineae of the Venezuelan Mountains. Grana 29:119-128

Schüler L, Behling H (2010) Characteristics of Poaceae pollen grains as a tool to assess palaeoecological grassland dynamics in South America. Veget Hist Archaeobot 20. doi:10.1007/s00334-0100264-0

Scott L (2002) Grassland development under glacial and interglacial consitions in southern Africa: review of pollen, phytolith and isotope evidence. Palaeogeogr Palaeoclimatol Palaeoecol 177:47-57

Sklenár P, Balslev H (2005) Superpáramo plant species diversity and phytogeography in Ecuador. Flora 200:416-433

Soriano A, León RJC, Sala OE, Lavado RS, Deregibus VA, Cauhépé MA, Scaglia OA, Veláquez CA, Lemcoff JH (1992) Río de la Plata Grasslands. In: Coupland RT (ed) Natural grasslands (Ecosystems of the World 8A), 1st edn. Elsevier, Amsterdam, pp 367-407 
Strömberg CAE (2004) Using phytolith assemblages to reconstruct the origin and spread of grass-dominated habitats in the great plains of North America during the late Ecocene to early Miocene. Palaeogeogr Palaeoclimatol Palaeoecol 207:239-275

ter Braak CJF, Smilauer P (1997) Canoco for Windows. Version 4.54. Biometris. Plant Research International, Wageningen

The R Foundation for Statistical Computing (2008) R. Version 2.6.2. The R Foundation for Statistical Computing

Tweedle JC, Edwards KJ, Fiedler NRJ (2005) Multivariate statistical and other approaches for the separation of cereal from wild
Poaceae pollen using a large Holocene dataset. Veget Hist Archaeobot 14:15-30

Watson L, Dallwitz MJ (1992) The grass genera of the world: descriptions, illustrations, identification, and information retrieval; including synonyms, morphology, anatomy, physiology, phytochemistry, cytology, classification, pathogens, world and local distribution, and references. Source: http://delta-intkey.com, Access Date: 2008 